\title{
Is governance enough? Assessing municipal capacity and CSO participation for complex service delivery
}

\author{
Renzo de la Riva Agüero ${ }^{1}$ \\ Indiana University - Bloomington
}

\begin{abstract}
Municipalities in the Global South are at the forefront of climate action. They suffer severe weather hazards that have increased their vulnerability and exposed their populations, infrastructure, and operations to unprecedented risk. These impacts are surpassing the local capacity to address them effectively via service provision. However, service performance seems to vary depending on the complexity level of the service itself. Given the implications of waste management for climate change mitigation and adaptation, this article uses a panel dataset of Peruvian municipalities to examine whether local governance factors, such as the administrative capacity of waste offices and active, locally embedded Civil Society Organizations (CSOs) involvement, equally influence the performance of two of its services ranging in complexity. Preliminary findings suggest that waste office administrative capacity is associated with improved performance in both services, simple and complex, while neighborhood-based CSOs are crucial for increased simple waste service delivery but not for providing the more complex one. Deliberative governance spaces of local collaboration are not associated with either service. This suggests that strengthening waste management administrative capacity might have primary importance to deliver complex services in particular, and that CSO participation may not have crucial implications for this type of service, contrary to expectations.
\end{abstract}

Keywords: Local governments, Waste management, Complex services, Administrative capacity, Civil society organizations, Governance, Global south, Peru, Climate change action.

\section{DRAFT MANUSCRIPT}

\footnotetext{
${ }^{1}$ The author is deeply grateful for the support of Aníbal Sánchez Aguilar, Deputy Head of the National Statistics Institute of Peru, José Valdivia Morón, General Secretary of the Ministry of Environment of Peru, and Verónika Mendoza Díaz, Specialist from the Solid Waste Management General Division of the Ministry of Environment of Peru, for their support and generosity in obtaining the data for this research. The author is especially thankful for the permanent encouragement and very insightful comments made by Jennifer N. Brass throughout the development of this paper. Generous feedback from Claudia N. Avellaneda, Matthew Baggetta, Sergio Fernandez, Lauren M.

MacLean, Sean Nicholson-Crotty, Ricardo A. Bello-Gómez, Anthony J. DeMattee, and members of the Brass Club and the Ostrom Workshop at Indiana University - Bloomington has also significantly enriched this work. The author takes full responsibility for any omissions and errors.
} 
Climate change has produced severe weather hazards that have increased the vulnerability of municipalities in the Global South and exposed their populations, infrastructure, and operations to unprecedented risk (IPCC 2015). These impacts are challenging and surpass the capacity of municipalities to address them effectively, especially municipalities that are administratively weak and have limited engagement of civil society and ambivalent political leaders (Anguelovski and Carmin 2011; Aylett 2015; Bulkeley and Betsill 2015, 140; Chu et al. 2016; Ostrom 2009). This situation implies that adaptation initiatives, which aim to minimize potential harm, and mitigation regulations and incentives, which are implemented to reduce greenhouse gas emissions (GhG), may be difficult to implement well.

Central to adequately tackling climate phenomena in the Global South is understanding the key local governance conditions that municipalities currently have, so as to uncover how they might be able to provide more complex services associated with climate change action moving forward. While limited resources constitute a significant impediment for municipal performance in the Global South, less knowledge exists about the organizational capabilities that may matter at the office level when services differ in complexity. Similarly, it is unclear whether the involvement of organized civil society groups in service provision can continue to improve performance as services become more complex. Understanding how municipal administrative capacity, civil society organizations (CSO), and the resulting collaborative governance influence the delivery of services ranging in complexity is thus crucial. Therefore, the primary aim of this article is to provide insights about this gap in the literature, mainly focusing on how municipal administrative capacity and organized civil society involvement affect performance when services become increasingly complex. The role of collaborations between civil society and the local government is also assessed.

Solid waste management is a relevant case for this question for several reasons. Waste management is a critical municipal responsibility that has multiple social and economic implications. When it fails, its consequences primarily affect the most vulnerable sectors, generating problems of public health and disease control; lower property value and private investment; and, exposing its employees, usually low-income women, to risk (Akinbile and Yusoff 2011; Fobil et al. 2008; Kaza et al. 2018; Schübeler et al. 1996; UN-Habitat 2010;). However, scholars and practitioners often overlook its relationship to climate change. Waste directly contributes 3-5\% to human-generated GhG emissions, mainly from methane, which are produced by poor collection, disposal, incineration, and management (Ackerman 2000; UNEP 2010; UN-Habitat 2010). This gas is considerably more damaging than carbon dioxide in the short and long term, and climate researchers expect it to increase significantly by 2050 if higher waste generation from population growth is not adequately managed (IPCC 2007, 212; Kaza et al. 2018, 118). Thus, understanding how to achieve waste management mitigation measures is crucial, even if waste emissions are relatively small compared to other sources of emission (Carmin et al. 2012; Gore and Robinson 2009; Schreurs 2008). The importance of waste management for adaptation is equally evident, although it has not received sufficient scrutiny (Anguelovski and Carmin 2011; Anguelovski et al. 2014; Lehmann et al. 2015; Pasquini et al. 2015). Cities that have poor municipal waste management and then experience extreme weather events, such as heavy rain and flooding associated with climate change, are also vulnerable to environmental disasters. Possible consequences are the obstruction of drainage and sewage systems as well as destroyed dumpsites, landfills, and other vital infrastructure used to handle solid waste and its derivatives, all of which worsen flooding and related damages (Kaza et al. 
2018, 119). Environmental threats are thus further aggravated by the consequences of waste mismanagement and poor local governance.

Thus, it is possible to associate waste mismanagement with problems of administrative capacity. Local government collaboration with, or substitution by, CSOs for service delivery may also affect performance outcomes, especially in contexts of weak bureaucratic capacity. Civil society involvement likely matters because it enhances or replaces governmental limitations, with evidence indicating that it also helps improve service delivery performance (Auerbach 2017; Loeffler and Bovaird 2016; Brass 2016; Cammett and MacLean 2014). However, waste management is a multipronged service. It involves sequentially-provided services that have distinct characteristics and hence varying requirements, including: diligent planning and statistical projections; meticulous operational processes; close internal coordination with other municipal offices; political support to strengthen capacity and allocate necessary resources; and, collaboration with civil society to support in the provision of collection, recycling, composting, and disposal services (Botello-Álvarez 2018; de Sousa Dutra et al. 2018; Fredericks 2018; Hoornweg and Bhada-Tata 2012; Kaza et al. 2018; Marino et al. 2018). Providing this service thus demands strong administrative capacity, high municipal costs, as well as civil society involvement (Abarca-Guerrero et al. 2013; Aleluia and Ferrão 2017; Kaza et al. 2018; Lohri et al. 2014; Ostrom 2009; Schübeler et al. 1996; UN-Habitat 2010;). However, not all of its associated services are equally intricate, and some comparable municipalities may not be able to provide a more complex service, even when they can do a more straightforward one. For waste management, for example, it is useful to contrast solid waste collection from the streets to waste disposal.

Globally, and especially in the developing world, it is harder for municipalities to provide waste management services of greater complexity, such as waste disposal, relative to more simple ones, such as waste collection from the streets. In practice, this translates into sufficiently clean streets, but also waste dumped in informal open holes with no control or treatment. Although this shows one way in which waste management adds to overall GhG emissions and complicates adaptation plans (Kaza et al. 2018), this differential performance may reveal the administrative weaknesses for providing more demanding services. However, it may also question whether the involvement of organized civil society groups, through partnerships with municipalities or actual substitution, can help boost performance when services are more complex.

Therefore, using panel data methods this study examines Peruvian municipalities, asking the following questions: Why are some local governments successful at collecting waste while at the same time blatantly failing to dispose of it, while other, similarly resourced municipalities can do both? Could CSO effectively support local governments improve performance, when services become more complex? What insights does this performance gap provide about the role of local collaborative governance on the delivery of services ranging in complexity?

This research contributes to the advancement of knowledge on issues related to local governance and complex service delivery in the Global South. It engages with research on organizational theory, administrative capacity, non-state provision, collaborative governance, waste management, and the political economy of service delivery, in the fields of political science and public administration. It hypothesizes that while improvements in municipal waste management administrative capacity and the involvement of locally active CSOs may strongly support improvements in a simple service, such as waste collection, only more waste management administrative capacity may help raise performance in a more complex service, 
such as waste disposal. In the latter service, CSOs are not expected to have an influential role. Moreover, local collaborative governance that include civil society in decision-making is expected to increase the performance of both types of services. Preliminary results confirm the expectations about the role of administrative capacity and CSOs but not of local collaborative governance. It contributes to the literature, on the one hand, by highlighting the added value of looking inside the administrative capacity of municipal bureaucracies and assessing CSO involvement in complex service delivery in the Global South and, on the other, by exploring whether the degree to which municipalities collaborate with civil society actors may influence the differential performance of services of distinct complexity.

This article starts with a discussion of the literature on administrative capacity, civil society organizations, and governance, that support the hypotheses. It is followed by a presentation of the context of waste management in Peru. The data and empirical strategy are then described, before presenting the preliminary findings of the study. It ends with a discussion of the results and some initial conclusions.

\section{Literature Review and Hypotheses}

\section{Administrative Capacity}

Studies on administrative capacity that focus on service delivery outcomes usually do so without considering the differences in complexity between specific services. Not understanding these distinctions reduces our knowledge about how administrative capacity matters when analyzing the performance of services ranging in complexity, especially if a municipal office is significantly failing in the provision of one of them. International development agencies do identify key administrative capabilities and reforms for performance in an "intensive [and varied] service" such as waste management (Hoornweg and Bhada-Tata 2012, 1). Among these skills are managing contracts; procurement processes; human resource management; technical, planning, financial, and operational knowledge; and, leading community and political relations (Hoornweg and Bhada-Tata 2012; Kaza et al. 2018). However, academic and applied research on municipal bureaucracies and service delivery in developing countries do not explicitly explain whether, how, and which administrative characteristics, independently or in aggregate, matter for the existence of performance differentials between services of distinct complexity (Avellaneda 2009; Faguet 2004; Falleti and Cunial 2018; Grindle 2007; Tankha et al. 2019; Lieberman 2015; Pepinsky et al. 2017). This work thus leaves unnoticed the degree to which relevant offices within a bureaucracy are sufficiently specialized and equipped to deliver specific services. While these approaches to capacity are valuable, it is crucial to examine the internal municipal conditions to learn about the role of administrative capacity on the performance of services of different complexity. This information can be gathered at the office or unit level by looking at the administrative resources available, how appropriate or specialized these resources are for a specific service, and how they ultimately influence that service's performance, as classical organizational theory suggests (Galbraith 2002; Lawrence and Lorsch 1967; Mintzberg 1983; Thompson 1967). Features of the structure and procedures of organizations -including office or unit specialization- as well as their resources, may thus be critical for task performance. Therefore, rather than examining capacity in aggregate and for all services, it is possible to obtain a more accurate understanding of administrative capacity by examining the degree of specialization and equipment of a municipal office or unit responsible for delivering a particular type of service. This research approaches administrative capacity in this way. 
Like other public services, waste services have varying levels of complexity, even within the same process (Batley and Mcloughlin 2015; Post 2018). Waste management thus has varied and complex administrative requirements. Planning and implementation of this overarching service demand administrative capacity to diagnose problems, project waste generation changes, and devise plans accordingly; operationalize multiple management strategies, many times of low political and social exposure; and, coordinate with numerous stakeholders (Abarca-Guerrero et al. 2013; Okot-Okumu and Nyenje 2011; Srivastava et al. 2015). It has several stages, and only in the implementation process, it involves the collection, segregation, transportation, treatment, and disposal of waste (Aleluia and Ferrão 2016; Kaza et al. 2018). In addition to their condition as waste management stages, they are also services in and of themselves. Administrative demands also vary in magnitude depending on the complexity of the services, which are thus diverse.

For example, the provision of collection services entails matching routines with available waste picking personnel, cleaning equipment, operational vehicles, and drivers. With a minimal level of planning, municipal managers can figure out how to structure the routines and distribute personnel to waste picking or driving and schedule the procurement of equipment for this waste service (Kaza et al. 2018; UN-Habitat 2010; USAID 2018). Since it is highly visible and thus socially and politically salient, its implementation and solutions to problems also tend to be accomplished at a higher speed than other services.

By contrast, disposal services require specialized infrastructure, such as a landfill, to treat and contain waste, or recycling, to segregate and process reusable waste. Ideally, disposal sites also need leachate containment geomembranes and tanks, as well as perimetric fences. Planning the implementation and management of these inputs require significantly more experienced and trained personnel and administrative units with more elaborate policy tools and procedural regulations (Abarca-Guerrero et al. 2013; Jeswani and Azapagic 2016; Kjeldsen et al. 2002). Moreover, these infrastructure projects take more time to put into operation and, since dumpsites or landfills are usually on the outskirts of cities, disposal services may receive insufficient societal and political attention to push for solutions while triggering NIMBY (not-in-mybackyard) resistance.

The cost differences between waste collection and disposal services are also remarkable. Developing countries, which typically focus first on waste collection, allocate about $80 \%$ of their waste management budgets to this service, which is a stark contrast with the $10 \%$ assigned by higher-income countries that also have higher disposal capacity (Aleluia and Ferrão 2017; Hoornweg and Bhada-Tata 2012; Kaza et al. 2018; Lohri et al. 2014; USAID 2018). Concerning their different human resource needs, one Peruvian municipal waste administrator acknowledged that "it is not necessary to have sophisticated HR for collection but ... disposal needs a diverse team of professionals ... which we don't have, and [this] affects our work" (de la Riva Agüero, forthcoming).

This evidence raises questions as to how much complexity municipal bureaucracies are capable of handling when delivering a service, such as waste disposal, in a context that increasingly requires them to do so urgently and efficiently. For instance, in Peru, $60 \%$ of all 1,874 municipalities collect waste daily or at least every other day, and $70 \%$ improperly dispose of it using informal open-air dump sites (INEI 2015; MINAM 2016). These differences are also observed in other countries' cities and are affected by the organizational, social, and thus political implications of providing disposal services relative to collection (Kaza et al. 2018; Shekdar 2009). The degree of administrative capabilities, and local governance as a whole, may 
thus be essential in this regard (Abarca-Guerrero et al. 2013; Aleluia and Ferrão 2017; Schübeler et al. 1996).

What this comparison illustrates is that it is not accurate to assume that all services can be equally provided by the same administrative and governance capabilities, especially if one service is more complex than the other. Therefore, examining conditions and processes within municipalities is essential to understand whether the available administrative capabilities are sufficient to adequately provide services regardless of their complexity as well as how these are affected by external pressures and unpredictabilities (Galbraith 2002; Hannan and Freeman 1984; Lawrence and Lorsch 1967; Mintzberg 1983; Pfeffer and Salancik 2003; Thompson 1967). This classical, applied approach to administrative capacity centered on its within conditions, is often overlooked by current approaches to the study of organizational performance, climate action, and waste management in a context of increasing environmental threats (Anguelovski et al. 2014; Kaza et al. 2018). Additionally, facing this challenge and the associated uncertainty is likely to aggravate already existing limitations in municipalities, including deeply embedded organizational weaknesses in their structures and administrative operations. Contrasting the performance of waste services ranging in complexity and examining their corresponding administrative capacity is, therefore, a necessary contribution.

\section{Organized Civil Society Involvement}

On the other hand, scholars have also found that the involvement of organized civil society improves public service delivery performance (Auerbach 2017; Cammett and MacLean 2014). However, it remains unclear if successful outcomes are possible when services have different complexity levels. In the Global South, mainly in cities with less state presence, civil society tends to get involved in the decision-making and delivery process of public services, such as waste management (UN-Habitat 2010). Residents organize to demand, collaborate, or coproduce services with local governments. In the case of waste, they participate in meetings about service issues and planning, and also take part in the sweeping, recycling, and disposing of waste. Many of those directly involved in some aspect of waste management are people informally employed by the waste sector and vulnerable groups, usually low-income women and their children who are stigmatized as a result (Fredericks 2009; Kaza et al. 2018; Vidanaarachchi et al. 2006). Because of this social characteristic, and the technical intricacies of certain waste services, their involvement can be trivialized by the local government, typically limiting it to street sweeping, waste picking, and recycling (Abarca-Guerrero et al. 2013; Botello-Álvarez 2018; USAID 2018). Yet, regardless of the task, civil society actors are also genuinely motivated to engage with this service because they care about the environment and their communities (de la Riva Agüero, forthcoming).

This type of civil society-municipality collaboration to enhance service delivery can expand the performance gap in favor of waste collection because of the relatively higher civil society involvement in it. The participation of CSOs in either service is thus crucial in this study.

Yet, improvements in service performance may not just result from the participation of any organized civil society actor. It may depend on the specific organizational features of the group. Some research finds that adequate service delivery is more likely when civil society is organizationally strong and formal, inclusive and participatory, rooted in the context in which it operates, and holds collaborative relationships with government that also strengthen bureaucratic capacity (Batley 2006; Brass 2016; Cammett and MacLean 2011, 2014; Clayton et al. 2000; Devas and Grant 2003; Putnam et al. 1993; Robinson and White 1997). This may be particularly 
the case in municipalities with high poverty levels, and despite the number of organized nonstate actors present (Torpey-Saboe 2015). The outcomes and relationship types, however, may depend on the specific service sector, the objectives, context, and extent of the involvement of civil society actors, and how government (or elite interest) reacts to their presence (Coston 1998; Nelson-Nuñez 2019). However, others claim that the efforts of CSOs, especially NGOs with weak embeddedness in society and that are not membership-based, do not produce the expected structural social transformations that address profound socioeconomic inequities (Banks et al. 2015). Similarly, others have found that, to the contrary, the participation of nonstate actors in service delivery -under particular circumstances- may reduce bureaucratic capacity by taking away this opportunity to hone its apparatus or through the conflictual relationships that emerge (Brass 2016, 140; Fernando 2011; Edwards and Hulme 1996; Pfeiffer 2003; Whaites 1998). This perception, nonetheless, is usually based on the assumption that these civil society actors are strong and organized.

Thus, there are no guarantees that civil society participation will enhance delivery outcomes, especially for the most vulnerable sectors and if the most connected and wealthy are more proactively engaged (Beall 2001; Devas and Grant 2003; Grillos 2017; McNulty 2013, 2019; Sheely 2015; Wood 1997). This means that simply examining participation will not directly elucidate questions regarding the role of civil society on service delivery. What all these findings imply is that to better understand the role on service delivery of the involvement of societal actors, research may need to assess the organizational characteristics of those civil society actors, their embeddedness in the context, how they are engaging in public issues, and the administrative capacity of government.

Another important factor for the effective involvement of civil society in service delivery is the transparency of their relationship with the communities they represent and with government (Devas and Grant 2003; Putnam et al. 1993). For instance, relations based on clientelism and patronage have a negative effect on service performance (Batley et al. 2012; Grindle 2007, 2012; Nelson 2007). In contrast, and in time, transparent involvement is believed to build trust, attitudes of collaboration, social support networks, and pressure on public authorities, especially where participation is higher. This seems to create more responsive service provision, even in weakly- or non-democratic political regimes (Putnam et al. 1983; Putnam 1988; Putnam et al. 1993; Tsai 2007). Some scholars, however, claim that effective civil society participation on service delivery in poor urban communities is actually influenced by the extent to which participants share an ethnic identity. The argument is that more homogeneous communities are more likely to collaborate because they are able to ensure compliance by using social sanctioning and cooperation norms as a result of their social ties (Habyarimana et al. 2007, 2009). Other research finds that participation itself does increase attention on poor sectors (Besley et al. 2005; Speer 2012) although some studies claim that pro-poor targeting and service delivery outcomes may be contingent on the stage in which the pertinent civil society groups participate (Grillos 2017; Brass et al. 2012). These findings indicate that, in addition to which societal sectors end up participating and how, the stage in the delivery process may also be central for service performance.

In the context of waste management, the effectiveness of CSO involvement in service delivery performance, commonly prioritizing waste collection, may, therefore, depend on the organizational strength and embeddedness of the group. Locally-based CSOs with more robust organizational capabilities may have a closer working relationship with the municipal waste office as well as more negotiating power. The expected result is that such CSOs could have a 
more influential voice in decision-making and municipal responsiveness to their concerns and needs as collaboration partners. In turn, and subject to the degree to which a more equitable collaboration addresses service-related issues, this interaction may produce performance benefits for the waste service receiving attention. Therefore, locally embedded CSOs involved in waste management with more transparent, collaborative, and long-standing relationships with their local governments may be more likely to obtain better performance. This could be especially the case if municipalities have the capacity to adequately manage CSO involvement across different waste services.

However, it is possible to observe performance differences if CSO participation is higher in one service (or stage) of waste management, such as waste collection, relative to another service, as waste disposal, in favor of the former. Yet, service performance might also be contingent on the complexity of the waste service itself, regardless of the CSO's organizational strength, embeddedness, or partnership with the local government. A key missing aspect from the literature is acknowledging that services have varying levels of complexity, even within the same process, as in the case of waste management (Batley and Mcloughlin 2015; Post 2018, 124125). This study thus challenges the assumption that the effect on service performance of CSO involvement remains unchanged even if the complexity of a service varies. The degree of embeddedness in the community, social group cohesion, and how its organizational characteristics match the complexity of a service may be important in this regard, since it is possible that different organizational features may be necessary as service complexity changes.

\section{Collaborative Governance}

The interaction between administrative capacity and CSOs is crucial, which entails examining how collaborative governance may explain waste service performance in general, on the one hand, as well as performance differences when contrasting waste services of distinct complexity, on the other. A range of governance relationships between government and civil society have been studied extensively to explain performance (Batley 2006, 2011; Brinkerhoff 2002; Brinkerhoff and Brinkerhoff 2011; Coston 1998; Denhardt and Denhardt 2015; Emerson et al. 2012; McGuire 2006; Osborne and McLaughlin 2004; Ostrom 1996). This interaction has been mainly approached in the form of the collaboration or coproduction of public services, which generally occurs when both paid public employees and (usually unpaid) service users (individuals or groups) make significant, active, and explicit contributions in the provision of a service (Bovaird 2007; Brandsen and Pestoff 2006; Brandsen and Honingh 2016; Brass 2016; Nabatchi et al. 2017; Ostrom 1996; Thomson and Perry 2006). But it can also be seen in substitution relationships or in contracting out. When governments (national or local) fail to provide essential services, mostly due to issues with administrative capacity, nonstate actors organize at the local or community levels to provide or find a way to have access to needed services. As a result, nonstate actors sometimes fully substitute the role of government while other times only partially substituting (or supplementing) it in specific areas where government is weaker (Batley and Mcloughlin 2010; Brass 2012; Cammett and MacLean 2011; Clayton et al. 2000; Post et al. 2017; Robinson and White 1997).

In contrast, governments with more capacity and financial resources may outsource certain services to individuals or private contractors not representing civil society groups. In these cases, the primary idea of the government is to provide services more effectively and efficiently, though not necessarily equitably, usually leading to reductions in personnel and equipment costs (Birdsall and Nellis 2003, 2005; Brinkerhoff and Brinkerhoff 2015; Brown and 
Potoski 2003; Post 2014; Raadschelders and Lee 2011; Van Slyke 2003). Nonetheless, the fundamental difference between coproduction and substitution from outsourcing is that, in the former two, organized civil society groups have an active role and that the relationship with government may not be as motivated by efficiency and cost-saving considerations. The contrary occurs in outsourcing, where the relationship is with a for-profit private business or individuals. Alternatively, states provide services directly without the involvement of any other actor (Post et al. 2017).

One crucial limitation in the collaborative governance literature is that it does not assess in detail the level of administrative capacity of public agencies nor the complexity of the service to analyze how governance influences service provision. This work tends to focus on the study of collaboration characteristics, determinants of collaboration and coproduction outcomes, civil society involvement types and their relationship with state agencies (Bryson et al. 2006, 2015; Loeffler and Bovaird 2016; Mcloughlin 2011; Zambrano et al. 2017). However, when bureaucratic administrative capacity is limited and services are underprovided, or not at all, collaboration becomes less likely because this central partner cannot contribute toward the goals of a collaboration of this kind (Agranoff 2007, 157; Babiak and Thibault 2009; Brinkerhoff 2002; Cammett and MacLean 2011; Loeffler and Bovaird 2016; Page et al. 2015). In these cases, civil society tends to step up and substitute or support the role of government to ensure that services are provided (Brass 2016; Mcloughlin 2011; Nelson-Nuñez 2019; Post et al. 2017).

Nonetheless, while this literature considers different governance scenarios, it leaves unclear how performance outcomes from different collaborative governance types might vary when incorporating into the analysis the relative complexity of the services provided, as in the case of waste collection and disposal. These are central questions that this research will explore.

In light of the preceding discussion, this study suggests the following hypotheses:

Hypothesis 1: Administrative capacity specific to waste management and the presence of active locally-embedded CSOs are positively, and strongly, associated with improvements in waste collection performance (i.e. a simple service).

This means that for the streets to be clean, waste collection performance in municipalities in the Global South benefit when these two conditions are met. This claim also illustrates that the streets are expected to be clean, or at least partially clean, even if municipal administrative capacity is low, by having an active local CSO, which may substitute or supplement municipal waste capacity. Municipalities could thus continue to provide this simple service, despite administrative difficulties. However, this performance is not expected in the case of complex service provision (i.e., waste disposal) because services of this nature require higher municipal administrative capacity that cannot be otherwise replaced. Therefore,

Hypothesis 2: Administrative capacity specific to waste management is positively, but moderately, associated with improvements in proper waste disposal performance (i.e. a complex service). However, the presence of active locally embedded CSOs is not associated with increased performance of this service.

The relationship between waste management capacity and waste disposal performance is expected to be moderate, or less strong, because it is likely that the municipal offices providing this service are structured, and thus more capable, to manage waste collection. The simpler 
delivery implications of the latter and its salience to the public and politicians may induce waste administrators to more proactively build up the administrative needs of the office. This study hence also argues that the involvement of CSOs with these bureaucracies is particularly important when the service is simple. More complex services, however, cannot be provided via CSOs when municipal capacity is low. What this statement indicates is that, on the one hand, CSOs could not substitute or supplement government in the provision of services when they are more complex and, on the other, that administrative capacity may be a primary determinant of performance when service complexity increases.

Nonetheless, the delivery of services with direct societal implications, as waste collection and disposal, need strong, collaborative governance relationships between a municipal government and civil society, where the latter participates in decision-making processes. This is expected to be particularly true in local governments facing multifaceted limitations, which is common for those in the Global South. Collaborations with strong societal presence may increase the likelihood that issues that would otherwise go unaddressed, due to their complexity of lack of salience, receive adequate attention. As a result,

Hypothesis 3: Local collaborative governance with civil society participation in decisionmaking is positively associated with performance improvements in both waste collection and proper disposal services.

These collaborative governance interactions may also be considered a form of coproduction at the decision-making level that result in the drafting of local policy measures and budgeting plans.

\section{The Context of Waste in Peru}

Peru currently has a total of 1,874 municipalities distributed across 25 regional governments (comparable to US states but with less political and fiscal autonomy). It has two types of municipalities or local governments: Provincial municipalities, which are similar to US counties, and district municipalities, equivalent to US cities. All reference to municipalities in this study is about the latter type of local government. Both provincial and district municipalities have specified jurisdictions and functions, with provincial governments prevailing over districts on specific tasks. Provincial municipalities manage their territories apart from the district municipalities it contains, and serve as the provincial capital. Overall, Peruvian cities vary in size, capacity, as well as the extent of civil society involvement in the delivery of services (Aragon and Casas 2008; Jaramillo and Wright 2015; Loayza et al. 2011; McNulty 2013; World Bank 2010). Urbanization level and ecological region are key features associated with differences across cities.

One of the primary administrative responsibilities attributed to both municipality types as a result of decentralization is the delivery of waste management services. Waste tends to be collected daily or every other day, though some municipalities do so with less frequency. For waste disposal, they employ several different methods, including the use of landfills, dumpsites, recycling, burning, and composting. Most municipalities utilize more than one of these simultaneously due to the lack of landfills or insufficient space in those available (MINAM $2016,21)$. Since there are a total of 35 formal landfills in the country, which have increased in 
recent years, ${ }^{2}$ and currently serve a total of 115 municipalities, the majority of Peruvian municipalities resort to a combination of the other methods. Municipal waste management is thus a significant cause of environmental issues in Peru.

The national average waste generation per capita has remained approximately the same in recent years, ${ }^{3}$ at 0.52 kilograms per day, ranging from 0.65 to 0.41 . Nonetheless, there are some significant differences at the municipal level within each regional government (MINAM 2018). Some noteworthy discrepancies persist, however, when analyzing municipal waste generation and waste management over time. In 2002, the estimated total municipal solid waste generation was 12,986 metric tons per day, or about 4.74 million metric tons that year. While municipalities collected $73.7 \%$ of this total, they only properly disposed of $19.7 \%$ in formal landfills (MINAM $2016,13)$. In 2014, waste production increased to approximately 7.5 million metric tons of municipal solid waste, of which roughly $32 \%$, or 2.4 million metric tons, were properly disposed of in landfills. Of the remaining 5.1 million metric tons, 3.6 million metric tons were dumped in informal open-air sites by municipalities themselves, after their personnel had collected it from the streets. This amount represents $71 \%$ of the total amount of waste generated that year (INEI 2015, 324).

More recently, in 2016, about 8.36 million metric tons where collected by 1,818 municipalities, or $98 \%$ of all 1,851 municipalities existing that year. Although only $23 \%$ (or 433 ) disposed of some portion of their collected waste in landfills, about $79 \%$ (or 1,463) used open-air dumpsites to get rid of some part of it (INEI 2018, 465-467). In 2017, 1,836 municipalities collected 8.13 million metric tons of waste, adding 18 more municipalities in one year. This indicates that less waste was collected by same by more cities but representing the same proportion of municipalities as the previous year, or $98 \%$, out of a total of 1,872 cities existing in 2017. 22\% (or 416) of municipalities used landfills to dispose of part of their waste and $79 \%$ (or 1,484) used open-air dumpsites (INEI 2019, 448-450). Compared to 2015, however, 2016 and 2017 show increasingly worse waste disposal conditions. In 2015, 1,777 municipalities collected approximately 7.63 million metric tons of waste, which is $95 \%$ of all 1,842 municipalities found that year (INEI 2016, 422). Yet, with regards to disposal, 572 municipalities used landfills (or $31 \%$ ) and 1,278 dumped their trash in open locations (or 69\%) (INEI 2016, 424). As a result of this worsening waste disposal performance, about 5,859 acres of deteriorated land was observed across 1,585 different locations in the country in 2018 (MINAM 2018). On the other hand, waste collection services seem to be managed with fewer complications, even improving, as 94 more municipalities collected waste at least every other day in $2013(1,019)$ relative to $2016(1,113)$ (INEI 2015, 2016, 2018).

Performance challenges for the delivery of waste disposal, relative to collection services, are evident. An additional administrative limitation that Peruvian municipalities confront is the lack of revenue from waste management fees along with their poor taxation capabilities (IDB 2012; World Bank 2017). Municipal waste revenues are thus usually less than the budget needed to deliver the service as a whole. As a result, they depend on transfers from the national government. While low revenue collection could affect the financial sustainability of waste services, weak taxation capacity might reflect more on the overall credibility of municipalities for service delivery, the administrative strength of their finance offices, and its revenue collection enforcement mechanisms (McNulty and Guerra García 2019).

\footnotetext{
${ }^{2}$ As of early 2020.

${ }^{3}$ The period considered for this calculation is 2013 through 2017.
} 
Furthermore, qualitative case-study research reveals that the primary waste-related duties of municipal waste offices are to oversee the monthly hiring of trash collection teams, the occasional acquisition of their gears (e.g., mouth masks, uniforms, boots, gloves), and solving other administrative issues (de la Riva Agüero, forthcoming). These shortcomings and collection-centered waste operations are further aggravated by the fact that some municipalities simultaneously share their waste duties with the provision of other public services and lack trained personnel (de la Riva Agüero, forthcoming). In this context, waste administrators make decisions regarding the delivery of services that have different complexity levels.

\section{Data, Variables, and Methods}

To test these hypotheses, this study uses a unique panel dataset of all 1,874 Peruvian municipalities covering the period of 2014, 2016 and 2018. It uses regression methods with the objective of identifying how variations in municipal waste management administrative capacity characteristics, the presence of active locally embedded CSOs, and local collaborative governance affect the performance of waste collection and proper waste disposal, controlling for general municipal capacity, political, socioeconomic, and geographic. Variation is expected in each year examined across municipalities, due to the significantly different municipal characteristics and conditions. However, less variation is expected overtime in each municipality due to the few years assessed and their temporal proximity. More temporal variation is expected at a higher level of aggregation, within provinces, which are one step above municipalities, due to the municipal diversity at that level. These expectations are confirmed by an analysis of the data.

The panel dataset is unique because it has been cleaned, complied, and created with municipal-level data from different sources and information registries in the Peruvian public sector for the purpose of this research. The data come from multiple public agencies, such as the Ministry of Environment, Ministry of Finance, National Jury of Elections, and National Statistics Institute of Peru. The main sources of information are the National Registry of Municipalities of Peru (RENAMU, for its acronym in Spanish), administered by the National Statistics Institute (INEI, for its acronym in Spanish); the Solid Waste Management Information System (SIGERSOL, for its acronym in Spanish) administered, by the Ministry of Environment (MINAM, for its acronym in Spanish); the Government Information Database (INFOGOB, for its acronym in Spanish), administered by the National Jury of Elections, and; the government budget spending database, administered by the Ministry of Finance.

\section{Dependent Variables}

The two dependent variables used measure solid waste collection and solid waste disposal performance. The objective is to examine the performance of these two different services, focusing on the extent to which they are provided according to their conceptual definitions in the waste management literature (Abarca-Guerrero et al. 2013; Aleluia and Ferrão 2016; Kaza et al. 2018; Shekdar 2009; UN-Habitat 2010; USAID 2018;).

Collection performance. The performance of this service is evaluated through the extent to which waste is collected by municipal employees, focusing on whether the streets are clean after waste is gathered. This is operationalized in two ways. One approach measures collection frequency, which is the number of times municipal employees collect waste from the streets. It 
reflects the frequency, in days per week, in which collection routines are deployed around the municipality to gather waste from households and public spaces. The other measure captures performance through the quantity of waste collected by the municipality. It is operationalized by the reported amount of waste collected, in tons per day, per 1,000 people.

Municipal waste quantity data for 2014 were reported in one of six categories, some of which had wide quantity ranges, such as "from 50 to less than 100 tons per day" (category five). To obtain a more accurate waste collection quantity value for this year, three estimation steps were taken. First, the growth or decline rate from 2016 to 2018 was calculated and used to obtain a 2014 collection quantity. Second, those cases with an estimate from the first step that was below or above their selected category range in 2014 were adjusted to the mid-point of that category. This was applied only to those cases belonging to categories one through three (below one ton/day, one to less than three tons/day, or three to less than nine tons/day, respectively). However, a third step was applied to those cases with an estimated value outside their 2014 quantity range and that fell under category four, five, or six that year (nine to less than 50 tons/day, 50 to less than 100 tons/day, or 100 or more tons/day, respectively). A random data check confirmed that the resulting estimates approximated their 2016 and 2018 values and were within their selected 2014 waste collection quantity category.

Disposal performance. The second dependent variable is defined as the degree to which waste is properly disposed of. Proper disposal performance is operationalized by adding the percent of waste disposed of in landfills and through recycling methods, out of the total waste disposed of by each municipality. The other, improper disposal methods, include dumping waste on informal, open-air holes and burning.

\section{Independent Variables}

The main independent variables of this study are waste management administrative capacity and the presence of active, locally embedded CSOs. The other key independent variable is local collaborative governance.

Waste management administrative capacity. It refers to the internal capabilities or competences of a (municipal) bureaucracy that support the planning, management, and implementation of waste management policy with the purpose of effectively and efficiently achieving its expected outcomes. Using the approach of classical organizational theory scholars (Galbraith 2002; Lawrence and Lorsch 1967; Mintzberg 1983; Thompson 1967), this concept is operationalized by examining the degree to which the municipal office responsible for waste management is internally specialized, which means having differentiated management features or components for this service (i.e., organizational structure, internal and external coordination processes, policy documents). Exploratory factor analysis is used to capture the latent concept of waste management administrative capacity through different dimensions measuring whether the municipality has waste and environmental management policy instruments and an organizational structure. A waste management administrative capacity index is constructed using the first factor in the pattern matrix, which has an eigenvalue of 2.18 (above the 1 eigenvalue threshold). This indicates that the factor, or latent variable, explains much of the variance of the observed variables used to run the factor analysis. Table 1 shows the eigenvalues of the factors obtained and their rotated factor loadings. 
Table 1. Waste Management Administrative Capacity Index: Eigenvalues and Pattern Matrix

\begin{tabular}{|c|c|c|c|c|c|}
\hline Variable & Factor 1 & Factor 2 & Factor 3 & Factor 4 & Uniqueness \\
\hline WM Integral Plan & 0.3232 & 0.3776 & -0.0641 & -0.003 & 0.7488 \\
\hline WM Plan & 0.1798 & -0.2234 & 0.3475 & 0.0204 & 0.7966 \\
\hline WM System & 0.1702 & 0.323 & -0.054 & -0.0042 & 0.8638 \\
\hline WM Transformation Program & 0.138 & 0.2208 & 0.1053 & 0.0733 & 0.9158 \\
\hline Other WM Instruments & 0.158 & 0.006 & 0.1406 & -0.02 & 0.9548 \\
\hline Environmental Office & 0.5058 & 0.1054 & 0.2856 & -0.0358 & 0.6502 \\
\hline Environmental Diagnostic & 0.6715 & 0.0572 & 0.0748 & 0.0301 & 0.5394 \\
\hline Environmental Action Plan & 0.5822 & 0.014 & 0.0185 & 0.0307 & 0.6595 \\
\hline Environmental Policy & 0.674 & 0.0364 & -0.0037 & -0.0034 & 0.5444 \\
\hline Environmental Commission & 0.58 & 0.1595 & 0.0731 & -0.0547 & 0.6298 \\
\hline Eigenvalues & 2.17699 & 0.37779 & 0.12973 & 0.01232 & \\
\hline
\end{tabular}

Moreover, two additional key variables are included in the model to capture administrative capacity, which are specifically related to each waste service. The concept of service equipment, measures whether the municipality has differentiated operational resources or components (i.e., trained personnel, operational office resources, budget allocation, operational waste trucks) for each of the two services. Given the data available, this research operationalizes this concept through the number of waste collection vehicles, in the models using waste collection as the dependent variable, and the number of waste disposal equipment, for the models assessing waste disposal. The waste collection vehicles variable adds the total vehicles the municipality has, such as the number of collection trucks (different types), tricycles, and motorcars, all of which are used to provide this service. The waste disposal equipment variable computes the total the number of gatehouses, weight scales, waste loaders, and wheelbarrows employed for this service.

Active and locally embedded CSOs. This independent variable is conceptually defined as whether locally organized civil society groups (i.e., CSOs) participate in the decision-making of community issues in the municipality (Bovaird 2007; Cammett and MacLean 2014; Putnam et al. 1993). Therefore, it is operationalized by measuring the participation of neighborhood committees, which have evident roots in the community and are actively involved in local issues. Exploratory factor analysis is performed using different dimensions on neighborhood committee participation to more fully capture the concept of active, locally embedded CSO presence. A neighborhood committee participation index is constructed using the first factor in the pattern matrix, which provides an eigenvalue of 2.06. This indicates that the factor, or latent variable, explains much of the variance of the observed variables. Therefore, the index is used as the main independent variable to capture this concept. Table 2 shows the eigenvalues of each factor obtained for this index as well as their rotated factor loadings. 
Table 2. Neighborhood Committee Participation Index: Eigenvalues and Pattern Matrix

\begin{tabular}{lrrr}
\hline \multicolumn{1}{c}{ Variable } & Factor 1 & Factor 2 & Uniqueness \\
\hline & & & \\
Population participates in muni. management & 0.0985 & 0.1095 & 0.9783 \\
Population participates in Neighborhood Delegate Committees & 0.6528 & 0.0879 & 0.5662 \\
Neighborhood Delegate Committee installed & 0.915 & 0.0303 & 0.1618 \\
Neighborhood Delegate Committee active & 0.8853 & 0.0068 & 0.2163 \\
\hline Eigenvalues & 2.06188 & 0.01561 & \\
\hline
\end{tabular}

However, another measure is included to examine another type of active, locally embedded CSO. It assesses the concentration, in number of organizations per 1,000 people, of poverty alleviating CSOs in the municipality. These local organizations include community kitchens, nutrition organizations (i.e. "glass of milk"), mothers' clubs, youth organizations, and others. All of these groups exclusively provide social services and support to low-income families, mostly in poverty, which are usually single mothers and their children.

Collaborative governance. This independent variable evaluates the extent to which civil society participates in local decision-making arenas and coproduce policies with their local governments. It refers to the collaboration, arrangement, or relationship that a local government and civil society have on issues of local importance, that usually include discussions about the provision of public services, such as waste management. Exploratory factor analysis is used to measure this latent concept that could be found across different dimensions capturing participatory governance and policy coproduction. The first latent factor in the factor analysis pattern matrix has an eigenvalue of 1.19 and is used as the collaborative governance index. Table 3 shows the eigenvalues of each factor and their rotated factor loadings.

Table 3. Collaborative Governance Index: Eigenvalues and Pattern Matrix

\begin{tabular}{lrrrr}
\hline \multicolumn{1}{c}{ Variable } & Factor 1 & Factor 2 & Factor 3 & Uniqueness \\
\hline & & & & \\
Muni. implemented activities of the Local Coord. Committee (LCC) & 0.232 & 0.6184 & -0.006 & 0.5637 \\
LCC sessions held & 0.6695 & 0.1004 & 0.0609 & 0.538 \\
LCC number of sessions held & 0.5843 & 0.0208 & -0.0528 & 0.6554 \\
LCC participates in drafting the Concerted Muni. Devmt Plan & 0.2334 & 0.246 & 0.2643 & 0.8152 \\
LCC participates in the participatory budgeting & -0.0554 & 0.6443 & 0.0611 & 0.5781 \\
Population participates in Concerted Municipal Development Plan & 0.017 & 0.081 & 0.4285 & 0.8095 \\
Population participates in collaborative budgeting process & 0.0066 & 0.0159 & 0.4634 & 0.7849 \\
Population participates in formulation/control of local economic plans & 0.0278 & 0.0273 & 0.3943 & 0.843 \\
\hline Eigenvalues & 1.19056 & 0.67105 & 0.5506 & \\
\hline
\end{tabular}

\section{Control Variables}

Other variables are included in the analysis to control for alternative explanations of the two dependent variables. The first set reflect the administrative capacity of the municipality as a whole, or the general administrative capacity. Exploratory factor analysis is used to capture this latent variable and includes measures of the proportion of its total employees out of the total population, number of computers with internet access per municipal worker, whether the municipality has a cadastre of its jurisdiction and a cadastral information system, total municipal budget per capita, and different binary variables assessing its capacity to manage its results-based 
budgeting $(\mathrm{RBB})$ program. The factor that capture the latent variable is used to construct the general administrative capacity index, and has an eigenvalue of 3.65. Table 4 shows the eigenvalues of each factor and their rotated factor loadings.

Table 4. General Administrative Capacity Index: Eigenvalues and Pattern Matrix

\begin{tabular}{lrrrrr}
\hline \multicolumn{1}{c}{ Variable } & Factor 1 & Factor 2 & Factor 3 & Factor 4 & Uniqueness \\
\hline & & & & & \\
Muni. HR as \% of Total Pop. & 0.043 & -0.0456 & -0.0284 & 0.5209 & 0.724 \\
PCs with internet per Muni. Worker & -0.0024 & 0.0859 & 0.0355 & -0.0811 & 0.9848 \\
Cadastre Info. Systems & 0.0983 & 0.102 & 0.4864 & -0.0603 & 0.7397 \\
Municipal Cadastre & 0.0505 & 0.078 & 0.4571 & -0.0525 & 0.7796 \\
Global final muni. budget, per capita (USD) & -0.0225 & -0.0183 & -0.07 & 0.4814 & 0.7625 \\
RBB: goals of Concerted Muni Devmt Plan match Rural Devmt Plan & 0.1783 & 0.4954 & 0.1202 & -0.0538 & 0.7055 \\
RBB: Indicators verify completion of goals of Concerted Muni Devmt Plan & 0.2007 & 0.5785 & 0.0598 & -0.024 & 0.6209 \\
RBB: Has units responsible of implementing of goals & 0.2499 & 0.5228 & 0.063 & -0.0045 & 0.6602 \\
RBB: Mid-term goals of plan & 0.2569 & 0.5204 & 0.0112 & -0.0292 & 0.6622 \\
RBB: Budget correspondence with plan & 0.2511 & 0.5528 & 0.0409 & -0.0063 & 0.6296 \\
RBB: Generates social/econ/environmental stats. & 0.4356 & 0.2652 & 0.0588 & -0.0326 & 0.7354 \\
RBB: Performance indicators & 0.5003 & 0.2516 & 0.0748 & 0.0235 & 0.6803 \\
RBB: Transparency of budget info. & 0.3861 & 0.2327 & 0.2376 & -0.0017 & 0.7403 \\
RBB: Donor support in budget reports & 0.4014 & 0.2522 & 0.0528 & -0.002 & 0.7724 \\
RBB: HR incentives for results & 0.5203 & 0.199 & -0.0147 & -0.0083 & 0.6894 \\
RBB: Strategies to improve service delivery & 0.5286 & 0.2697 & 0.0819 & 0.0012 & 0.6411 \\
RBB: Public consultations to improve services & 0.5277 & 0.18 & 0.0137 & 0.0149 & 0.6887 \\
RBB: Efficiency/effectiveness indicators for public service coverage & 0.5132 & 0.2608 & 0.0698 & 0.0177 & 0.6635 \\
\hline Eigenvalues & 3.65194 & 0.62508 & 0.46305 & 0.37996 & \\
\hline
\end{tabular}

Since empirical research finds that the political capital, experience, and education of the mayor may help explain the effect of local politics on the performance of waste management (Abarca-Guerrero et al. 2013; Avellaneda 2012; UN-Habitat 2010), the analysis controls for the share of the electoral vote obtained by the elected mayor in the 2011 and 2016 municipal elections. This measure captures their electoral support during their tenure as mayors for the 2011-2014 and 2015-2018 periods, respectively. The model also controls for the influence of mayoral reelection, whether the mayor's party is a local or regional party (as opposed to a major national party or alliance), and if the mayor is female.

Peruvian municipalities experience significantly diverse contexts across the eight different ecological and hence geographic areas, which are mostly associated with higher altitudes, and distinct weathers and natural environments. Most prosperous cities in the country are in located the Pacific coast. Therefore, a binary variable is included to control for such differences and its potential influence on the two dependent variables. Moreover, to control for socioeconomic factors, the models account for municipal poverty levels and total population. 
Table 5. Descriptive Statistics

\begin{tabular}{|c|c|c|c|c|c|}
\hline & $\mathbf{N}$ & Mean & St. Dev. & Min & Max \\
\hline \multicolumn{6}{|l|}{ Dependent Variables } \\
\hline Waste Collection Frequency (days/week) & 5,561 & 3.97 & 2.58 & 0 & 7 \\
\hline Waste Collection Quantity, per 1,000 People (metric tons/day) & 5,435 & 0.56 & 2.94 & 0 & 181.03 \\
\hline Waste Properly Disposed (\%) & 5,593 & 27.78 & 40.51 & 0 & 100 \\
\hline \multicolumn{6}{|l|}{ Independent Variables } \\
\hline \multicolumn{6}{|l|}{ Waste Management Capacity (Overall) } \\
\hline WM Admin. Capacity Index & 5,525 & $(0.00)$ & 0.85 & $(0.80)$ & 2.26 \\
\hline WM Integral Plan & 5,525 & 0.23 & 0.42 & 0 & 1 \\
\hline WM Plan & 5,525 & 0.56 & 0.50 & 0 & 1 \\
\hline WM System & 5,525 & 0.45 & 0.50 & 0 & 1 \\
\hline WM Transformation Program & 5,525 & 0.05 & 0.22 & 0 & 1 \\
\hline Other WM Instruments & 5,525 & 0.04 & 0.20 & 0 & 1 \\
\hline WM Budget (per Capita \$) & 3,998 & 11.57 & 39.85 & 0 & 996.06 \\
\hline Environmental Office & 5,561 & 0.55 & 0.50 & 0 & 1 \\
\hline Environmental Diagnostic & 5,561 & 0.29 & 0.45 & 0 & 1 \\
\hline Environmental Action Plan & 5,561 & 0.23 & 0.42 & 0 & 1 \\
\hline Environmental Policy & 5,561 & 0.18 & 0.38 & 0 & 1 \\
\hline Environmental Commission & 5,561 & 0.23 & 0.42 & 0 & 1 \\
\hline \multicolumn{6}{|l|}{ Waste Management Capacity (Specific for each Service) } \\
\hline Waste Collection Vehicles (per squared mile) & 5,591 & 0.08 & 0.74 & 0 & 27.75 \\
\hline Waste Disposal Equipment (per 1,000 people) & 5,561 & 0.12 & 0.64 & 0 & 33.11 \\
\hline \multicolumn{6}{|l|}{ Civil Society Participation } \\
\hline Neihgborhood Committee Participation Index & 5,507 & 0.00 & 0.94 & $(0.95)$ & 1.18 \\
\hline No. CSOs (per 1,000 people) & 5,561 & 6.01 & 4.43 & 0 & 46.65 \\
\hline \multicolumn{6}{|l|}{ Governance } \\
\hline Participatory Governance Index & 5,323 & $(0.00)$ & 0.74 & $(1.04)$ & 2.93 \\
\hline \multicolumn{6}{|l|}{ Controls } \\
\hline Mayor Reelected & 5,416 & 0.18 & 0.38 & 0 & 1 \\
\hline Mayor's Vote Share & 5,513 & 34.98 & 10.46 & 0 & 91.67 \\
\hline Local Party & 5,513 & 0.63 & 0.48 & 0 & 1 \\
\hline Mayor Female & 5,417 & 0.03 & 0.17 & 0 & 1 \\
\hline General Admin. Capacity Index & 5,362 & 0.00 & 0.79 & (1.17) & 2.38 \\
\hline Poverty & 5,555 & 43.21 & 21.79 & 0.17 & 97.38 \\
\hline Total Population & 5,561 & 16,410 & 52,099 & 151 & $1,123,889$ \\
\hline Ecological Region & 5,561 & 3.59 & 1.95 & 1 & 8 \\
\hline
\end{tabular}

\section{Estimator}

All models discussed are ordinary least squares regressions using two-way fixed effects by province and year. Given that most of the variation in the dependent variables is explained by differences between municipalities, and that not much variation is expected at the municipal level in three years, using fixed-effects at the municipal level would remove most of that variation thus limiting possible explanations about how municipal characteristics relate to the dependent variables (Bello-Gómez, forthcoming; Krause et al. 2006). A two-way ANOVA test was performed to examine the variation of the dependent variables explained by differences in municipalities and in years. These results show that $81.4 \%$ of the variation in waste collection frequency, $36.6 \%$ of the variation in waste collection quantity, and $59.01 \%$ of the variation in proper waste disposal are explained by differences between municipalities. Therefore, the decision is to account for unobserved location-specific time-invariant correlations with regressors by using fixed-effects at the provincial level. However, given the differences in characteristics between municipalities in the same province, it is more likely that variation in the 
independent variables does exist at that level. So, using that rationale, it is more appropriate to use fixed effects via provincial dummy variables instead of municipal dummy variables. Following that logic, standard errors are also clustered on provinces to use less clusters and adjust for correlations between observations across different years municipalities in each provincial group (Cameron and Miller 2015).

\section{Preliminary Findings}

The preliminary findings from the main regression models are presented in Table 6 . It contains two models of waste collection performance, one assessing collection frequency (column 1) and another collection quantity (column 2), and one model of waste disposal performance, evaluating proper disposal (column 3). The total number of municipality-year observations in each model ranges from 3,586 to 3,612 , for the three years studied. It is important to note that the collection frequency and proper disposal models explain between 40 percent and 30 percent of the variation in these two waste management services, which indicates that those models perform well. The model of collection quantity explains 7 percent of the variation of this specific waste collection service.

The main variables of interest are the waste management administrative capacity index, including the measures of waste management capacity specific to each service; neighborhood committee participation index; and, collaborative governance index. The waste management capacity index is highly statistically significant in the collection frequency and proper disposal models, with positive coefficients, but not significant in the collection quantity model, at the 0.001 and 0.05 levels. This suggests that, all else equal, strengthening administrative capacity, at the municipal waste office level, is associated with increased waste collection frequency and proper waste disposal in landfills or through recycling methods. A one standard deviation increase in waste management administrative capacity is associated with a half-day increase in collection frequency per week and an additional 2 percent of waste properly disposed annually. Waste management capacity thus improve the performance of both simple and complex waste services. Similarly, the specific waste management capacity measures are positive and significant on all three models, confirming that these capacity equipments also raise waste service performance. Adding one more waste collection vehicle is associated with an increase in collection frequency of 0.11 days per week, or about 2.5 more hours, which is statistically significant at the 0.001 level. An extra collection vehicle increases the amount of waste collected per day in about 0.04 metric tons per day per 1,000 people, which translates into roughly 40 kilograms or 88.2 pounds. This is also statistically significant at the 0.001 level. Likewise, an extra disposal equipment improves proper disposal performance in about 3 percent each year.

The participation of active, locally embedded CSOs, such as neighborhood associations, is only strongly and positively associated with improved collection frequency performance. A one standard deviation increase in the neighborhood committee participation index is associated with an increase of 0.16 days per week in collection frequency, or approximately 4 hours per week. This relationship is significant at the 0.001 level. The participation of neighborhood associations does not show a statistically significant association with proper disposal performance, even though the coefficient is positive. However, the other measure of CSO participation, examining the role of the number of poverty-alleviating local organizations per 1,000 people, is negatively associated with collection frequency but positively with collection 
quantity. These relationships are significant at the 0.01 and 0.10 levels, respectively. This type of CSO shows no association with proper disposal, although the coefficient is positive.

Collaborative governance, on the other hand, is not associated with any of the three dependent variables, although it has negative coefficients on both waste collection measures and a positive coefficient on the proper disposal outcome variable.

Results from the control variables show a significant and positive association between the general administrative capacity of the municipality and collection frequency, at the 0.01 level, but none with collection quantity and proper disposal performance. A one standard deviation increase in the general administrative capacity index is associated with roughly 3.8 hours added to collection frequency routine each week. However, when mayors win elections with a higher share of the popular vote it is possible for collection frequency to slightly fall while proper disposal may have a very modest improvement. These associations are statistically significant at the 0.001 and 0.10 levels, respectively. Poverty is statistically significant and only negatively associated with collection quantity, at the 0.01 level. The ecological region variable is only significant and positively associated with collection frequency when comparing coastal municipalities using the other regions as base category, at the 0.001 level. 
Table 6. Two-Way Fixed Effects Regressions for Waste Collection and Disposal Performance

\begin{tabular}{|c|c|c|c|}
\hline & \multicolumn{2}{|c|}{ Waste Collection } & \multirow{2}{*}{$\begin{array}{l}\text { Waste Disposal } \\
\text { Properly Disposed } \\
\text { (\%) }\end{array}$} \\
\hline & $\begin{array}{l}\text { Frequency } \\
\text { (days/week) }\end{array}$ & $\begin{array}{c}\text { Quantity } \\
\text { (metric tons/day, } \\
\text { per } 1,000 \text { people) }\end{array}$ & \\
\hline \multicolumn{4}{|l|}{ Waste Management Capacity (overall) } \\
\hline \multirow[t]{2}{*}{ WM Admin. Capacity Index } & $0.521 * * *$ & -0.036 & $1.958^{*}$ \\
\hline & $(0.06)$ & $(0.06)$ & $(0.98)$ \\
\hline \multirow[t]{2}{*}{ WM Budget (per Capita \$) } & $0.002+$ & 0.001 & -0.001 \\
\hline & $(0.00)$ & $(0.000)$ & $(0.01)$ \\
\hline \multicolumn{4}{|c|}{ Waste Management Capacity (specific for each service) } \\
\hline \multirow[t]{2}{*}{ Waste Collection Vehicles (per sq. mile) } & $0.105^{* * *}$ & $0.037 * * *$ & \\
\hline & $(0.03)$ & $(0.01)$ & \\
\hline \multirow[t]{2}{*}{ Waste Disposal Equipment (per 1,000 people) } & & & $2.621+$ \\
\hline & & & -1.335 \\
\hline \multicolumn{4}{|l|}{ Civil Society Participation } \\
\hline \multirow[t]{2}{*}{ Neighborhood Committee Participation Index } & $0.162^{* * *}$ & 0.061 & 0.374 \\
\hline & $(0.05)$ & $(0.04)$ & $(0.75)$ \\
\hline \multirow[t]{2}{*}{ No. CSOs (per 1,000 people) } & $-0.057^{* *}$ & $0.013+$ & 0.05 \\
\hline & $(0.02)$ & $(0.01)$ & $(0.27)$ \\
\hline \multicolumn{4}{|l|}{ Governance } \\
\hline \multirow[t]{2}{*}{ Collaborative Governance Index } & -0.026 & -0.058 & 0.792 \\
\hline & $(0.06)$ & $(0.06)$ & $(1.05)$ \\
\hline \multicolumn{4}{|l|}{ Controls } \\
\hline \multirow[t]{2}{*}{ General Admin. Capacity Index } & $0.158 * *$ & 0.074 & 0.441 \\
\hline & $(0.05)$ & $(0.08)$ & $(0.84)$ \\
\hline \multirow[t]{2}{*}{ Mayor Reelected } & -0.067 & -0.048 & 1.051 \\
\hline & $(0.15)$ & $(0.05)$ & $(2.56)$ \\
\hline \multirow[t]{2}{*}{ Mayor's Vote Share } & $-0.021 * * *$ & 0.000 & $0.156+$ \\
\hline & $(0.01)$ & $(0.00)$ & $(0.09)$ \\
\hline \multirow[t]{2}{*}{ Local Party } & -0.009 & 0.048 & 0.036 \\
\hline & $(0.10)$ & $(0.06)$ & $(1.79)$ \\
\hline \multirow[t]{2}{*}{ Mayor Female } & -0.105 & 0.028 & -3.284 \\
\hline & $(0.23)$ & (0.09) & $(4.04)$ \\
\hline \multirow[t]{2}{*}{ Poverty } & -0.006 & $-0.006 * *$ & -0.048 \\
\hline & $(0.01)$ & $(0.00)$ & $(0.07)$ \\
\hline \multirow[t]{2}{*}{ Total Population } & 0.000 & 0.000 & 0.000 \\
\hline & $(0.000)$ & $(0.000)$ & $(0.000)$ \\
\hline \multirow[t]{2}{*}{ Ecological Region (coast) } & $1.258^{* * *}$ & 0.052 & -8.343 \\
\hline & $(0.28)$ & $(0.13)$ & $(6.06)$ \\
\hline \multirow[t]{2}{*}{ Intercept } & $6.167^{* * *}$ & $0.551^{* *}$ & $48.841^{* * *}$ \\
\hline & $(0.41)$ & $(0.20)$ & (6.32) \\
\hline Observations & 3,612 & 3,586 & 3,612 \\
\hline R-squared & 0.40 & 0.07 & 0.30 \\
\hline $\mathrm{BIC}$ & $15,208.83$ & $14,403.10$ & $36,007.95$ \\
\hline
\end{tabular}

Standard errors in parentheses

$+p<0.10,{ }^{*} p<0.05,{ }^{* *} p<0.01,{ }^{* * *} p<0.001$ 


\section{Discussion}

The preliminary results presented here strongly support the first two hypotheses that waste management administrative capacity and active, locally rooted CSOs have a strong and positive association with improvements in simple waste collection performance while only waste management administrative capacity has a positive association with complex waste disposal performance. This type of CSOs do not seem to have a role on proper waste disposal performance. However, initial findings reject the third hypothesis that collaborative governance is positively associated with performance improvements in both waste collection and disposal services, regardless of their complexity.

The results shown in Table 6 suggest that the administrative capacity of municipal waste offices, captured through an index and service-specific waste capacity equipments, has crucial implications for improving the performance of waste management services ranging in complexity. This evidence is confirmed across the two waste collection models and the waste disposal model. On the other hand, while it is generally expected that the active involvement of well-organized civil society actors, particularly those embedded in the communities in which they operate, is likely to produce better performance outcomes for all public services, the initial results reject those assumptions. Preliminary findings indicate that the involvement of actively and locally embedded CSOs is crucial for simple services, such as waste collection, but the relevance of their participation disappears when services become more complex. This suggests that strong, service-specific administrative capacity might be necessary to deliver complex services, and that CSO participation does not seem to be sufficient to help improve its performance.

Another interesting finding is that these local CSOs are important to increase collection frequency but not collection quantity, which implies that collection teams are going out more often but not necessarily picking up more waste. This suggest that municipalities face equipment limitations that affect the quantity of waste they can carry each time. This is a possible explanation given the positive and significant association that collection vehicles have with collection quantity, showing that more vehicles likely improve the amount of waste collected. Another possibility is that local governments are actually sending out collection teams to appease public demands for collection but are not necessarily doing anything about increasing collection quantity. The limited human resource capabilities that municipal waste offices generally have may also preclude them from rigorously supervising how well collection teams carry out their routines and how much of the waste is collected or the proportion of a municipality's jurisdiction is actually covered by these teams.

The concentration of poverty-alleviating CSOs is positively correlated with municipal poverty levels, indicating that it is likely that poorer local governments have more such organizations, which in turn have more members. Some poor municipalities also tend to employ their most vulnerable residents to deliver waste management services, usually related to collection (de la Riva Agüero, forthcoming). Therefore, the fact that an increase in the concentration of these CSOs, and in turn of their members, is negatively associated with collection frequency but positively with collection quantity, with very small coefficients, suggests that their involvement in waste collection is more efficient because, as a collective, they likely need to go out less often and actually help collect more waste. Being a labor-intensive activity, waste collection quantity might benefit from more people willing and available to do the job with more commitment, because of their livelihood needs. 
One possible explanation about why collaborative governance is not associated with waste collection and disposal is that waste management issues are possibly not a matter of pressing discussion in these deliberative spaces. At the very least, the waste-related topics that are brough to the table are not relevant to produce a significant influence on waste service performance, regardless of complexity. Topics such as municipal infrastructure construction, poverty-alleviating measures, local economic development and support for local businesses, and budget allocation to other critical services may have more salience.

\section{Conclusion}

One of the most pressing questions of our time is how governments can better respond to climate change. This is particularly true in municipalities in the Global South, who face constant climate threats with weak local capabilities to address them. They suffer severe weather hazards that have increased their vulnerability. These impacts surpass the local capacity to address them effectively via service provision, despite the involvement of organized civil society actors that tend to enhance performance. Additionally, service performance seems to vary depending on the complexity level of the service itself. However, scarcely any public administration or political science scholarship has examined how local governance factors, such as administrative capacity and the participation of locally embedded CSOs, affect performance when services become more complex. Complex service provision is especially demanding for struggling municipalities that attempt to creatively take action with a limited administrative capacity to deliver them specifically. This difficulty may extend to CSOs engaged with public service issues in their communities, challenging the notion that service performance improves when they are locally involved, regardless of its complexity.

Given the implications of municipal waste management for climate change mitigation and adaptation, this article uses waste service provision as a case to examine how variation in local governance factors may have differential effects on the performance of two services of distinct complexity. Particularly, it compares the performance of a simple service, such as waste collection from the streets, and a complex service, such as waste disposal, to understand how municipal administrative capacity, organized civil society involvement, and the resulting collaborative governance influence the performance of waste services ranging in complexity. An empirical analysis of Peruvian municipalities shows that while stronger waste offices and the participation of neighborhood-based CSOs likely increase simple service performance, such as that of waste collection, waste office strengthening but not the involvement of neighborhoodbased CSOs seems to help improve complex service performance, such as that of waste disposal. Local collaborative governance with civil society participation in the decision-making does not seem to support the performance of either waste service.

These conclusions are preliminary and need to be confirmed with more years of data and further research. However, at the very least, the initial results of this article suggest that our understanding of the role that service-specific municipal administrative capacity, CSO involvement, and the resulting forms of collaboration have on service performance is improved, and possibly more precise, when we distinguish the complexity of a service and conduct separate analyses. 


\section{References}

Abarca-Guerrero, Lilliana, Ger Maas, and William Hogland. 2013. "Solid waste management challenges for cities in developing countries.” Waste Management 33(1): 220-232.

Ackerman, Frank. 2000. "Waste management and climate change." Local Environment 5(2): 223229.

Agranoff, Robert. 2007. Managing within networks: Adding value to public organizations. Washington, DC: Georgetown University Press.

Akinbile, Christopher O and Mohd S Yusoff. 2011. "Environmental Impact of Leachate Pollution on Groundwater Supplies in Akure, Nigeria." International Journal of Environmental Science and Development 2(1): 81.

Aleluia, Joao and Paulo Ferrão. 2017. "Assessing the costs of municipal solid waste treatment technologies in developing Asian countries." Waste Management 69: 592-608.

. 2016. "Characterization of Urban Waste Management Practices in Developing Asian Countries: A New Analytical Framework Based on Waste Characteristics and Urban Dimension." Waste Management 58: 415-29.

Andrews, Kenneth T., Marshall Ganz, Matthew Baggetta, Hahrie Han, and Chaeyoon Lim. 2010. "Leadership, membership, and voice: Civic associations that work." American Journal of Sociology 115(4): 1191-1242.

Anguelovski, Isabelle and JoAnn Carmin. 2011. "Something Borrowed, Everything New: Innovation and Institutionalization in Urban Climate Governance." Current opinion in environmental sustainability 3(3): 169-75.

Anguelovski, Isabelle, Eric Chu, and JoAnn Carmin. 2014. "Variations in Approaches to Urban Climate Adaptation: Experiences and Experimentation from the Global South." Global Environmental Change 27: 156-67.

Aragon, Fernando, and Carlos Casas. 2008. "Local Governments' Capacity and Performance: Evidence from Peruvian Municipalities." Caracas: CAF - Development Bank of Latin America. Working Paper 2008/06.

Arnstein, Sherry R. 1969. "A ladder of citizen participation." Journal of the American Institute of Planners 35(4): 216-224.

Auerbach, Adam Michael. 2017. "Neighborhood Associations and the Urban Poor: India's Slum Development Committees." World Development 96: 119-35.

Avellaneda, Claudia N. 2009. “Municipal Performance: Does Mayoral Quality Matter?” Journal of Public Administration Research and Theory 19: 285-312. 
Aylett, Alexander. 2015. "Institutionalizing the Urban Governance of Climate Change Adaptation: Results of an International Survey.” Urban Climate 14: 4-16.

Babiak, Kathy and Lucie Thibault. 2009. "Challenges in multiple cross-sector partnerships." Nonprofit and Voluntary Sector Quarterly 38(1): 117-43.

Baggetta, Matthew and David M. Bredenkamp. 2019. "Systematic social observation in the study of civil society organizations." Sociological Methods \& Research: 0049124119826148.

Banks, Nicola, David Hulme, and Michael Edwards. 2015. "NGOs, states, and donors revisited: Still too close for comfort?" World Development 66: 707-718.

Batley, Richard. 2011. "Structures and strategies in relationships between non-government service providers and governments." Public Administration and Development 31(4): 306-19.

. 2006. "Engaged or divorced? Cross-service findings on government relations with nonstate service-providers." Public Administration and Development 26(3): 241-251.

Batley, Richard and Claire Mcloughlin. 2015. "The politics of public services: A service characteristics approach." World Development 74: 275-285.

2010. "Engagement with non-state service providers in fragile states: reconciling statebuilding and service delivery." Development Policy Review 28(2): 131-154.

Batley, Richard, Willy McCourt, and Claire Mcloughlin. 2012. "The Politics and Governance of Public Services in Developing Countries." Public Management Review 14: 131-44.

Beall, Jo. 2001. "Valuing social resources or capitalizing on them? Limits to pro-poor urban governance in nine cities of the south." International Planning Studies 6(4): 357-375.

Bello-Gómez, Ricardo A. (forthcoming). "Human resources in multilevel service provision: The effect of workforce size and educational attainment."

Besley, Timothy, Rohini Pande, and Vijayendra Rao. 2005. "Participatory democracy in action: Survey evidence from south India." Journal of the European Economic Association 3(23): 648-57.

Birdsall, Nancy and John R. Nellis. 2005. "Privatization reality check: Distributional effects in developing countries." In Reality check: The distributional impact of privatization in developing countries, eds. John R. Nellis and Nancy Birdsall. Washington, DC: Brookings Institution Press.

. 2003. "Winners and losers: Assessing the distributional impact of privatization." World Development 31(10): 1617-33. 
Botello-Álvarez, José Enrique, Pasiano Rivas-García, Liliana Fausto-Castro, Alejandro EstradaBaltazar, and Ricardo Gomez-Gonzalez. 2018. "Informal Collection, Recycling and Export of Valuable Waste as Transcendent Factor in the Municipal Solid Waste Management: A Latin-American Reality." Journal of Cleaner Production 182: 485-95.

Bovaird, Tony. 2007. "Beyond engagement and participation: User and community coproduction of public services." Public Administration Review 67(5): 846-860.

Brandsen, Taco and Marlies Honingh. 2016. "Distinguishing different types of coproduction: A conceptual analysis based on the classical definitions." Public Administration Review 76(3): 427-435.

Brandsen, Taco and Victor Pestoff. 2006. "Co-production, the third sector and the delivery of public services: An introduction." Public Management Review 8(4): 493-501.

Brass, Jennifer N. 2016. Allies or Adversaries: NGOs and the State in Africa. New York: Cambridge University Press.

. 2012. "Blurring boundaries: The integration of NGOs into governance in Kenya." Governance 25(2): 209-235.

Brass, Jennifer N., Sanya Carley, Lauren M. MacLean, and Elizabeth Baldwin. 2012. "Power for development: A review of distributed generation projects in the developing world." Annual Review of Environment and Resources 37: 107-136.

Brinkerhoff, Jennifer M. 2002. "Government-nonprofit partnership: A defining framework." Public Administration and Development 22(1): 19-30.

Brinkerhoff, Derick W. and Jennifer M. Brinkerhoff. 2015. "Public sector management reform in developing countries: Perspectives beyond NPM orthodoxy." Public Administration and Development 35(4): 222-237.

Brown, Trevor L. and Matthew Potoski. 2003. "Contract-management capacity in municipal and county governments." Public Administration Review 63(2): 153-164.

Bulkeley, Harriet and Michele M. Betsill. 2013. "Revisiting the Urban Politics of Climate Change." Environmental politics 22(1): 136-54.

Bryson, John M., Barbara C. Crosby, and Melissa Middleton Stone. 2015. "Designing and implementing cross-sector collaborations: Needed and challenging." Public Administration Review 75(5): 647-663.

. 2006. "The design and implementation of cross-sector collaborations: Propositions from the literature." Public Administration Review 66: 44-55. 
Cammett, Melani C. and Lauren M. MacLean. 2014. "The political consequences of non-state social welfare: An analytical framework." In The politics of non-state social welfare, eds. Melani C. Cammett and Lauren M. MacLean. Ithaca: Cornell University Press.

. 2011. "Introduction: The political consequences of non-state social welfare in the Global South." Studies in Comparative International Development 46(1): 1-21.

Carmin, JoAnn, Isabelle Anguelovski, and Debra Roberts. 2012. "Urban Climate Adaptation in the Global South: Planning in an Emerging Policy Domain." Journal of Planning Education and Research 32(1): 18-32.

Chu, Eric, Isabelle Anguelovski, and JoAnn Carmin. 2016. "Inclusive Approaches to Urban Climate Adaptation Planning and Implementation in the Global South." Climate Policy 16(3): 372-92.

Clayton, Andrew, Peter Oakley, and Jon Taylor. 2000. Civil society organizations and service provision. Geneva: United Nations Research Institute for Social Development, Civil Society and Social Movements Programme. Paper No. 2.

Collier, David, Henry E. Brady, and Jason Seawright. 2010. "Sources of leverage in causal inference: Toward an alternative view of methodology." In Rethinking social inquiry: Diverse tools, shared standards, eds. Henry E. Brady and David Collier. Lanham: Rowman and Littlefield.

Coston, Jennifer M. 1998. "A model and typology of government-NGO relationships." Nonprofit and Voluntary Sector Quarterly 27(3): 358-382.

de la Riva Agüero, Renzo. (forthcoming). "Administrative capacity as a black box of climate change action in the Global South: A case study exploring administrative capacity, complexity, and performance in the Peruvian waste management sector." State and Local Government Review.

Denhardt, Janet V., and Robert B. Denhardt. 2015. "The new public service revisited." Public Administration Review 75(5): 664-672.

de Sousa Dutra, Renato Meira, Luciana Harue Yamane, and Renato Ribeiro Siman. 2018. "Influence of the Expansion of the Selective Collection in the Sorting Infrastructure of Waste Pickers' Organizations: A Case Study of 16 Brazilian Cities." Waste Management 77: 50-58.

Devas, Nick and Ursula Grant. 2003. "Local government decision-making - citizen participation and local accountability: some evidence from Kenya and Uganda." Public Administration and Development 23(4): 307-316.

Edwards, Michael and David Hulme. 1996. "Too close for comfort? The impact of official aid on nongovernmental organizations." World development 24(6): 961-973. 
Emerson, Kirk, Tina Nabatchi, and Stephen Balogh. 2012. "An integrative framework for collaborative governance." Journal of Public Administration Research and Theory 22(1): $1-29$.

Faguet, Jean-Paul. 2004. "Does decentralization increase government responsiveness to local needs?" Journal of Public Economics 88(2-4): 867-893.

Falleti, Tulia G., and Santiago L. Cunial. 2018. Participation in Social Policy: Public Health in Comparative Perspective. Cambridge: Cambridge University Press.

Falleti, Tulia G. 2005. "Sequential theory of decentralization: Latin American cases in comparative perspective." American Political Science Review 99(3): 327-346.

Fernando, Jude. 2011. The political economy of NGOs: State Formation in Sri Lanka and Bangladesh. London: Pluto Press.

Fobil, Julius N, Nathaniel A Armah, Jonathan N Hogarh, and Derick Carboo. 2008. "The Influence of Institutions and Organizations on Urban Waste Collection Systems: An Analysis of Waste Collection System in Accra, Ghana (1985-2000)." Journal of environmental management 86(1): 262-71.

Fredericks, Rosalind. 2018. Garbage Citizenship: Vital Infrastructures of Labor in Dakar, Senegal: Duke University Press.

. 2009. "Wearing the pants: The gendered politics of trashwork in Senegal's capital city." Hagar 9(1): 119 .

Galbraith, Jay R. 2002. Designing organizations: An executive guide to strategy, structure, and processes. San Francisco, CA: Jossey-Bass.

George, Alexander L. and Andrew Bennett. 2005. Case Studies and Theory Development in the Social Sciences. Cambridge: MIT Press.

Gerring, John. 2017. "Qualitative methods.” Annual Review of Political Science 20: 15-36.

Grillos, Tara. 2017. "Participatory budgeting and the poor: tracing bias in a multi-staged process in solo, Indonesia." World Development 96: 343-358.

Grindle, Merilee. 2012. Jobs for the boys: Patronage and the state in comparative perspective. Cambridge: Harvard University Press.

. 2007. Going local: Decentralization, democratization, and the promise of good governance. Princeton: Princeton University Press. 
Habyarimana, James, Macartan Humphreys, Daniel N. Posner, and Jeremy M. Weinstein. 2009. Coethnicity: Diversity and the dilemmas of collective action. New York: Russell Sage Foundation.

. 2007. "Why Does Ethnic Diversity Undermine Public Goods Provision?" American Political Science Review 101(4): 709-725.

Hannan, Michael T. and John Freeman. 1984. "Structural inertia and organizational change." American Sociological Review 49(2): 149-164.

Hoornweg, Daniel and Perinaz Bhada-Tata. 2012. What a Waste: A Global Review of Solid Waste Management. Urban Development Series. Washington, DC: World Bank.

Inter-American Development Bank (IDB). 2012. Peru: Project for the development of solid waste management systems in priority areas. Washington, DC: Inter-American Development Bank. Accessed through http://idbdocs.iadb.org/wsdocs/getdocument.aspx?docnum=EZSHARE-17666355-2551.

Intergovernmental Panel on Climate Change (IPCC). 2015. Climate change 2014: Synthesis report. Geneva: IPCC.

. 2007. Climate Change 2007: The physical science basis. Working Group I contribution to the Fourth Assessment Report of the Intergovernmental Panel on Climate Change. New York: Cambridge University Press.

Jaramillo, Miguel, and Glenn D. Wright. 2015. "Participatory democracy and effective policy: Is there a link? Evidence from rural Peru." World Development 66: 280-292.

Jeswani, Harish K., and Adisa Azapagic. 2016. "Assessing the environmental sustainability of energy recovery from municipal solid waste in the UK." Waste Management 50: 346-363.

Kapiszewski, Diana, Lauren M. MacLean and Benjamin L. Read. 2015. Field research in political science: Practices and principles. Cambridge: Cambridge University Press.

Kaza, Silpa, Lisa Yao, Perinaz Bhada-Tata, and Frank Van Woerden. 2018. What a waste 2.0: A global snapshot of solid waste management to 2050. Washington, DC: The World Bank.

Kjeldsen, Peter, Morton A. Barlaz, Alix P. Rooker, Anders Baun, Anna Ledin, and Thomas H. Christensen. 2002. "Present and long-term composition of MSW landfill leachate: A review." Critical Reviews in Environmental Science and Technology 32(4): 297-336.

Krause, George A., David E. Lewis, and James W. Douglas. 2006. "Political Appointments, Civil Service Systems, and Bureaucratic Competence: Organizational Balancing and Executive Branch Revenue Forecasts in the American States." American Journal of Political Science 50(3): 770-787. 
Lawrence, Paul R., and Jay W. Lorsch. 1967. "Differentiation and integration in complex organizations." Administrative Science Quarterly 12(1): 1-47

Lehmann, Paul, Miriam Brenck, Oliver Gebhardt, Sven Schaller, and Elisabeth Süßbauer. 2015. "Barriers and Opportunities for Urban Adaptation Planning: Analytical Framework and Evidence from Cities in Latin America and Germany." Mitigation and adaptation strategies for global change 20(1): 75-97.

Levin, Kevin, David Rich, Yamil Bonduki, Michael Comstock, Dennis Tirpak, Heather McGray, Ian Noble, Kathleen Mogelgaard, and David Waskow. 2015. Designing and preparing Intended Nationally Determined Contributions (INDCs). World Resource Institute and United Nations Development Program.

Lieberman, Evan. 2015. "The Comparative Politics of Service Delivery in Developing Countries." In The Oxford Handbook of Politics of Development, eds. Carol Lancaster and Nicolas van de Walle. Oxford: Oxford University Press.

- 2005. "Nested analysis as a mixed-method strategy for comparative research." American Political Science Review 99(3): 435-452.

Loayza, Norman V., Jamele Rigolini, and Oscar Calvo-Gonzalez. 2011. "More than you can handle: Decentralization and spending ability of Peruvian municipalities." Washington, DC: World Bank Policy Research. Working Paper 5763.

Loeffler, Elke, and Tony Bovaird. 2016. "User and community co-production of public services: What does the evidence tell us?" International Journal of Public Administration 39(13): 1006-1019.

Lohri, Christian Riuji, Ephraim Joseph Camenzind, and Christian Zurbrügg. 2014. "Financial sustainability in municipal solid waste management-Costs and revenues in Bahir Dar, Ethiopia." Waste Management 34(2): 542-552.

Marino, Arthur Lima, Gisele de Lorena Diniz Chaves, and Jorge Luiz dos Santos Junior. 2018. "Do Brazilian Municipalities Have the Technical Capacity to Implement Solid Waste Management at the Local Level?’. Journal of Cleaner Production 188: 378-86.

McGuire, Michael. 2006. "Collaborative public management: Assessing what we know and how we know it." Public Administration Review 66: 33-43.

Mcloughlin, Claire. 2011. "Factors affecting state-non-governmental organisation relations in service provision: Key themes from the literature." Public Administration and Development 31(4): 240-251.

McNulty, Stephanie L. and Gustavo Guerra Garcia. 2019. "Politics and promises: Exploring fifteen years of Peru's participatory decentralization reform." Public Organization Review 19(1): 45-64. 
McNulty, Stephanie L. 2013. "Participatory democracy? Exploring Peru's efforts to engage civil society in local governance." Latin American Politics and Society 55(3): 69-92.

Ministry of Environment of Peru (MINAM). 2018. National System of Environmental Information: National Indicators on Solid Waste. Accessed though: https://sinia.minam.gob.pe/indicadores/listado/383 . 2016. National Plan of Integral Solid Waste Management: 2016-2024.

Mintzberg, Henry. 1983. Structures in fives: Designing effective organizations. Englewood Cliffs, NJ: Prentice-Hall.

Nabatchi, Tina, Alessandro Sancino, and Mariafrancesca Sicilia. 2017. "Varieties of participation in public services: The who, when, and what of coproduction." Public Administration Review 77(5): 766-776.

National Statistics Institute of Peru (INEI). 2019. Environmental statistics annual report. 2018. Environmental statistics annual report. 2016. Environmental statistics annual report. 2015. Environmental statistics annual report.

Nelson, Joan M. 2007. "Elections, Democracy, and Social Services." Studies in Comparative International Development 41(4): 79-97.

Nelson-Nuñez, Jami. 2019. "Substitution or Facilitation: Service-Delivery NGOs and Political Engagement in the Peruvian Amazon." Comparative Political Studies 52(3): 445-477.

Okot-Okumu, James and Richard Nyenje. 2011. "Municipal solid waste management under decentralisation in Uganda." Habitat International 35(4): 537-43.

Osborne, Stephen P. and Kate McLaughlin. 2004. "The cross-cutting review of the voluntary sector: where next for local government-voluntary sector relationships?" Regional Studies 38(5): 571-580.

Ostrom, Elinor. 2009. A Polycentric Approach for Coping with Climate Change. Washington, DC: World Bank Policy Research. Working Paper 5095.

1996. "Crossing the great divide: coproduction, synergy, and development." World Development 24(6): 1073-1087. 
Page, Stephen B., Melissa M. Stone, John M. Bryson, and Barbara C. Crosby. 2015. "Public value creation by cross-sector collaborations: a theory and challenges of assessment." Public Administration 93(3): 715-732.

Pasquini, Lorena, Gina Ziervogel, Richard M Cowling, and Clifford Shearing. 2015. "What Enables Local Governments to Mainstream Climate Change Adaptation? Lessons Learned from Two Municipal Case Studies in the Western Cape, South Africa." Climate and Development 7(1): 60-70.

Pepinsky, Thomas B, Jan H Pierskalla, and Audrey Sacks. 2017. "Bureaucracy and Service Delivery." Annual Review of Political Science 20: 249-68.

Pfeffer, Jeffrey, and Gerald R Salancik. 2003. The external control of organizations: A resource dependence perspective. Stanford, CA: Stanford University Press.

Pfeiffer, James. 2003. "International NGOs and primary health care in Mozambique: The need for a new model of collaboration." Social Science \& Medicine 56(4): 725-738.

Post, Alison E. 2018. "Cities and politics in the developing world." Annual Review of Political Science 21: 115-133.

. 2014. "The politics of 'contracting-out' to the private sector: Water and sanitation in Argentina." In The politics of non-state social welfare, eds. Melani C. Cammett and Lauren M. MacLean. Ithaca: Cornell University Press.

Post, Alison E., Vivian Bronsoler, and Lana Salman. 2017. "Hybrid regimes for local public goods provision: a framework for analysis." Perspectives on Politics 15(4): 952-966.

Putnam, Robert D., Robert Leonardi, and Raffaella Y. Nonetti. 1993. Making democracy work: Civic traditions in modern Italy. Princeton: Princeton University Press.

. 1988. "Institutional performance and political culture: Some puzzles about the power of the past." Governance 1(3): 221-242.

Putnam, Robert D., Robert Leonardi, Raffaella Y. Nonetti, and Franco Pavoncello. 1983. "Explaining institutional success: The case of Italian regional government." American Political Science Review 77(1): 55-74.

Raadschelders, Jos C.N., and Kwang-Hoon Lee. 2011. "Trends in the study of public administration: Empirical and qualitative observations from Public Administration Review, 2000-2009." Public Administration Review 71(1): 19-33.

Raudenbush, Stephen W and Robert J Sampson. 1999. "Ecometrics: Toward a science of assessing ecological settings, with application to the systematic social observation of neighborhoods." Sociological methodology 29(1): 1-41. 
Reiss, Albert J. 1971. "Systematic observation of natural social phenomena." Sociological methodology 3: 3-33.

Robinson, Mark and Gordon White. 1997. The role of civic organizations in the provision of social services: towards synergy. Helsinki: UNU World Institute for Development Economics Research. Research for Action 37.

Schreurs, Miranda A. 2008. "From the Bottom Up: Local and Subnational Climate Change Politics." The Journal of Environment \& Development 17(4): 343-55.

Schübeler, Peter, Jürg Christen, and Karl Wehrle. 1996. "Conceptual framework for municipal solid waste management in low-income countries." United Nations Development Program Working Paper 9.

Seawright, Jason. 2016. Multi-method social science: Combining qualitative and quantitative tools. Cambridge: Cambridge University Press.

Sheely, Ryan. 2015. "Mobilization, participatory planning institutions, and elite capture: Evidence from a field experiment in rural Kenya." World Development 67: 251-266.

Shekdar, Ashok V. 2009. "Sustainable solid waste management: An integrated approach for Asian countries." Waste Management 29(4): 1438-1448.

Speer, Johanna. 2012. "Participatory governance reform: A good strategy for increasing government responsiveness and improving public services?" World Development 40(12): 2379-98.

Srivastava, Vaibhav, Sultan Ahmed Ismail, Pooja Singh, and Rajeev Pratap Singh. 2015. "Urban Solid Waste Management in the Developing World with Emphasis on India: Challenges and Opportunities." Reviews in Environmental Science and Bio/Technology 14(2): 317-37.

Tankha, Sunil, Sunita Ranabhat, Laxmi Dutt Bhatta, Rucha Ghate, and Nand Kishor Agrawal. 2019. "Disinterested agents or mismatched plans? Public administration capacities and climate change responses in the least developing countries." International Journal of Climate Change Strategies and Management 11(3): 372-391.

Thompson, James D. 1967. Organizations in action: Social science bases of administrative theory. New Brunswick: Transaction Publishers.

Thomson, Ann Marie and James L. Perry. 2006. "Collaboration processes: Inside the black box." Public Administration Review 66: 20-32.

Torpey-Saboe, Nichole. 2015. "Does NGO presence decrease government spending? A look at municipal spending on social services in Brazil." World Development 74: 479-488. 
Tsai, Lily L. 2007. Accountability without democracy: Solidary groups and public goods provision in rural China. Cambridge: Cambridge University Press.

United Nations Environment Programme (UNEP). 2010. Waste and climate change: Global trends and strategy framework.

United Nations Human Settlements Programme (UN-Habitat). 2010. Solid waste management in the world's cities: water and sanitation in the world's cities 2010. Washington, DC: UNHABITAT.

United States Agency for International Development (USAID). 2018. Sector environmental guideline: Solid waste. Accessed through https://www.usaid.gov/sites/default/files/documents/1860/SectorEnvironmentalGuideline s_SolidWaste_2018.pdf

Van Slyke, David M. 2003. "The mythology of privatization in contracting for social services." Public Administration Review 63(3): 296-315.

Vidanaarachchi, Chandana K, Samuel TS Yuen, and Sumith Pilapitiya. 2006. "Municipal Solid Waste Management in the Southern Province of Sri Lanka: Problems, Issues and Challenges." Waste Management 26(8): 920-30.

Wedeen. Lisa. 2010. "Reflections on ethnographic work in political science." Annual Review of Political Science 13: 255-272.

Whaites, Alan. 1998. "NGOs, civil society and the state: Avoiding theoretical extremes in real world issues." Development in Practice 8(3): 343-349.

Wood, Geoffrey D. 1997. "States without citizens: The problem of the franchise state." In NGOs, States and Donors: Too Close for Comfort?, eds. David Hulme and Michael Edwards. London: Macmillan.

World Bank. 2017. Peru: Building a more efficient and equitable fiscal decentralization system. Washington, DC: The World Bank.

2010. Peru: Evaluation of the participatory budgeting and its relation with the results based budgeting. Washington, DC: The World Bank. Accessed through http://documents.worldbank.org/curated/en/971021468085742271/Peru-Evaluación-delPresupuesto-Participativo-y-su-relación-con-el-presupuesto-por-resultados

Zambrano-Gutiérrez, Julio César, Amanda Rutherford, and Sean Nicholson-Crotty. 2017. "Types of coproduction and differential effects on organizational performance: Evidence from the New York City school system." Public Administration 95(3): 776-790. 